\title{
Evaluation of the analytical performance of Roche immunoturbidimetric immunoglobulin assays and comparing to Dade Behring immunonephelometer
}

\author{
Roche immüntürbidimetrik immunoglobulin analizlerinin analitik performans değerlendirmesi \\ ve Dade Behring immünnefelometri ile karşılaştırılması
}

Cevdet Züngün ${ }^{1}$, Fatma Meriç Yılmaz ${ }^{1,2}$, Bağdagül Çakır ${ }^{1}$

\begin{abstract}
Objective: The aim of this study is to evaluate the analytical performance of the Roche immunoturbidimetric immunoglubulin assays, and also compare the results obtained by Roche immunoturbidimetric method to Dade Behring II Nephelometer.

Methods: Low and high concentration patient samples and internal quality control materials were used to evaluate precision, limit of detection (LoD) linearity, and sample carry over of Roche immunoturbidimetric analyzer. External quality control results were used to evaluate accuracy. For method comparison, 451 patients serum were analyzed using Roche Hitachi Modular P System with an immunoturbidimetric method and Dade Behring BNII immunonephelometer with an immunonephelometric method.
\end{abstract}

Results: In precision study on Roche immunoturbidimetric immunoglobulin assays, imprecision values were $1.37 \%, 3.88 \%$ and $5.34 \%$ for $\lg G, A$ and $M$, respectively. Correlation coefficents between Roche immunoturbidimetric analysis and Dade Behring BN II immunonephelometer were $0.967,0.979$ and 0.939 for $\lg$, IgA and IgM respectively.

Conclusion: In immunoturbidimetric Roche Ig analyses precision for IgG was allowable according to the the desirable quality specifications. However, both IgA and IgM had higher imprecisions than the desirable total precision. Immunoturbidimetric Roche Ig analyses were found linear in the reference values but unreliable results were observed in the presence of excess antigen. The same samples performed on Roche analyzers needed to be diluted suggesting Dade Behring had wider linearity range than Roche immunoturbidimetric analyzer in the presence of excess antigen. J Clin Exp Invest 2014; 5 (3): 362-367

Key words: Ig G, Ig A, Ig M, immunoturbidimetry, immunonephelometry

\section{ÖZET}

Amaç: Bu çalışmanın amacı Roche immuntürbidimetrik immunoglobulin analizlerinin analitik performanslarının değerlendirilmesi yanında bu metot ile elde edilen sonuçların immunnefelometrik yöntem kullanılan Dade Behring II cihazı ile karşılaştırılmasıdır.

Yöntemler: Roche immuntürbidimetrik yöntemin tekrarlanabilirlik, alt ölçüm sınırı, linearite ve numune taşınma etkisi (carry over efekti) değerlendirmelerinde, düşük ve yüksek lg konsantrasyonlarına sahip hasta örnekleri ve iç kalite kontrol materyalleri kullanıldı. Doğruluk analizi dış kalite kontrol sonuçları değerlendirilerek yapıldı. 451 hasta serumu immuntürbidimetrik metot kullanan Roche Hitachi Modular P Sistem ve immunnefelometrik metot kullanan Dade Behring BNII immünnefelometride analiz edilerek metot karşılaştırması geçekleştirildi.

Bulgular: Roche immünoturbidimetrik immunoglobulin analizlerinin tekrarlanabilirlik çalışmalarında lgG için kesinlik değeri $1.37 \%$ iken, IgA ve IgM için kesinlik değerleri sırasıyla $3.88 \%$ ve $5,34 \%$ olarak tespit edildi. Roche immünoturbidimetrik ve Dade Behring nefelometrik IgG, A ve $\mathrm{M}$ analizleri arasındaki korelasyon katsayıları ise sırasıyla 0.967, 0.979 ve 0.939 olarak bulundu.

Sonuç: İmmünoturbidimetrik Roche Ig analizlerinde tekrarlanabilirlik IgA ve $\mathrm{M}$ için kabul edilebilir total presizyon limitlerinin üzerinde bulunurken, IgG için kabul edilebilir limitler dahilinde bulundu. İmmünoturbidimetrik Roche Ig analizleri için alt ölçüm sınırlarının üreticinin sağladığı bilgilerle uyum gösterdiği tespit edildi. İmmünoturbidimetrik Roche Ig analizlerinin referans aralıkları içerisinde lineer olduğu, ancak çok yüksek antikor konsantrasyonlarında güvenilmez sonuçların oluştuğu gözlendi. Dade Behring BNII nefelometri analizöründe çalışılan aynı örneklerin, Roche türbidimetrik metotla çalışıldığında dilüsyona ihtiyaç duyması, Dade Behring II otoanalizörlerinin daha geniş bir linearite aralığına sahip olduğunu ortaya koymuştur.

Anahtar kelimeler: Ig G, Ig A, Ig M, immünoturbidimetri, immünonefelometri

\footnotetext{
${ }^{1}$ Clinical Biochemistry, Ankara Numune Education and Training Hospital Ankara, Turkey

${ }^{2}$ Yıldırım Beyazıt University Faculty of Medicine Biochemistry Department Ankara, Turkey
}

Correspondence: Fatma Meriç Yılmaz,

Ankara Numune Education and Training Hospital Clinical Biochemistry, Ankara, Turkey Email: fatmamericyilmaz@hotmail.com 


\section{INTRODUCTION}

Turbidimetry and nephelometry are both based on the scattering of radiation by a solution containing dispersed particulate matter [1]. The main technical difference in nephelometry is that the amount of radiation scattered by the particles is measured by viewing at right angles to the incident light while in turbidimetry the amount of radiation transmitted by the suspension is measured. The fraction of the scattered radiation and the reasons directing the scatters such as the number of particles, their size and shape are the main factors in making the choice between turbidimetry and nephelometry. In the presence of many particles leading a large scale of scattering, turbidimetry generally yields more reliable results. On the other hand nephelometry is preferable at low concentrations of analytes owing to easier measuring of a small amount of scattered radiation than a change in density of transmitted radiation Immunoglobulins (Ig) G, A and M are part of analytes classified as "specific proteins" that have wide ranging clinical utility. Single radial immunodiffusion (RID) and electro-immunodiffusion which is a variation of RID have been early methods of immunoglobulin quantitation used in clinical settings. Ig testing performed using methodology of immunonephelometry or immunoturbidimetry on routine clinical chemistry analyzers providing faster results have replaced RID techniques. Automation of Ig quantitation on generalpurpose clinical chemistry systems provides random access, rapid analysis, high volume testing, and cost reduction [2]. The International Federation of Clinical Chemistry (IFCC) and Laboratory Medicine's Committee on Plasma Proteins has designated both immunonephelometry and immunoturbidimetry as reference methods for quantitation of $\lg G, \lg A$ and $\lg M$ in serum or plasma [3].

The aim of this study is to evaluate the analytical performance of the Roche immunoturbidimetric immunoglubulin $G, A$ and $M$ assays in terms of linearity in the presence of excess antigen, limit of detection (LoD) of the assays, sample carry over, precision and accuracy. Also a method comparison study was performed employing Dade Behring II nephelometer as the reference method for method validation of Roche immunoturbidimetric immunoglobulin assays.

\section{METHODS}

\section{Evaluation of Precision for Roche immunoturbidimetric Ig assays}

The precision studies were performed according to Clinical and Laboratory Standarts Institute Educa- tion Protocol 5 (CLSI EP-5A2), Evaluation of Precision Performance of Quantitative Measurement Methods [4]. Within-run imprecisions were determined using low and high concentration internal quality control materials. Within-run percentage coefficient variations ( $\mathrm{CVw} \%$ ) were based on 20 replicate measurements of selected samples per analytical run. Total precisions (CVa\%) were obtained measuring human serum aliquotes in an internal protocol as 1 run per day and 10 days.

\section{Limit of detections (LoD) of assays on Roche immunoturbidimetric Ig assays}

Twenty replicates of the lowest concentration calibrator material and saline were used to calculate the limit of blank (LoB) and LoD following CLSI EP17-A [5]. Standart deviations (SD) and mean values of saline (blank) were used to calculate LoB from the formula LoB = Meanblank + 1.45 SDblank. LoD was determined using LoB value and 1.645 fold SD of lowest concentration calibrator material mean value ( LoD $=$ LoB + 1.645.SD lowest calibrator level) [5]

\section{Assessment of linearity for Roche immunoturbidimetric Ig assays}

\section{Linearity across the reference range values}

In present study we also evaluated the linearity of Roche immunoturbidimetric $\lg G, A$ and $M$ assays across the range of reference intervals. Six dilutions (6 (high): 1 (low), through 1 (high): 6 (low)) of low and high level commercial quality control materials were analyzed. Diluted samples were run in duplicate in a single run on Roche Hitachi Modular P analyzer.

\section{Linearity in the presence of excess antigen}

Linearity was evaluated following the directions present in CLSI EP6-A [6]. Six dilutions derived from high and low concentration patient samples for each $\lg G, \lg A$ and $\lg M$ were used to assess linearity in the presence of excess antigen. All three samples were diluted 6 (high): 1 (low), through 1 (high): 6 (low). Diluted samples were run in duplicate in a single run on Roche Hitachi Modular P analyzer. The observed results were compared to the theoretical (calculated) results for each dilutions. Upper limits of linearity for $\lg G, \lg A$ and $\lg M$ were determined following $\pm 10 \%$ linearity recovery specifications between the equal concentration ranges of serial dilutions. The average concentration point that the diluted sample exceeded $\pm 10 \%$ linearity recovery was determined as the upper limit of linearity for related immunoglobulin. 


\section{Sample carry-over on Roche immunoturbidimetric Ig assays}

Three replicates of saline measurements $(\mathrm{s} 1, \mathrm{~s} 2$ and s3) immediately after three replicates of high concentration samples of $\operatorname{lgG}(2403 \mathrm{mg} / \mathrm{dL})$, IgA $(612 \mathrm{mg} / \mathrm{dL})$ and $\mathrm{lgM}(416 \mathrm{mg} / \mathrm{dL})$ assays (a1, a2 and a3 for each analytes) were performed to evaluate sample carry over. Carry over was calculated using the formula (s1-s3) / (a3-s3) [7,8].

\section{Evaluation of accuracy for Roche immunoturbidimetric Ig assays}

The retrospective results of our laboratory in RIQAS external quality results were observed to evaluate accuracy for the peer group of Roche Hitachi analyzer.

\section{Subjects and ethics}

451 patient specimens delivered to our laboratory from different clinics of our hospital for routine IgG, $\mathrm{A}$, and $\mathrm{M}$ testing were used in the present study. 222 of patients were male aged between $20-88$ years (mean age: $60.49 \pm 14.13$ ) and 229 of patients were female aged between 19-91 years (mean age: $61.45 \pm 14.31$ ). A total of 113 patients ( 57 male; 56 female) had a diagnosis of multiple myeloma. 93 patients (63 male and 30 female) had renal disorders as acute or chronic renal deficiency and nephrotic syndrome and 245 remaining were patients with various diagnoses including diabetes mellitus, anemia, leukocyte disorders, trombocytopenia, viral hepatitis and different malignancies. All procedures in the present study were approved by our institution's responsible committee in accordance with the Helsinki Declaration of 1975.

\section{Specimens and analyzers for method comparison study}

Fasting blood samples were obtained from patients to plain tubes. Sera were separated after centrifugation at $1500 \mathrm{~g}$ for 10 minutes and analyzed using Roche Hitachi Modular P System (Roche Diagnostics $\mathrm{GmBH}$ Mannheim, Germany) with an immunoturbidimetric method and Dade Behring BNII immunonephelometer (Dade Behring Canada Inc.) with an immunonephelometric method.

\section{Assessment of total error for Roche immunoturbidimetric Ig assays}

The total error (TE) can be calculated in a number of ways. The most usual way is to add bias and precision linearly [9]. We calculated TE for the immunoturbidimetric method according to the formula below;

$$
\mathrm{TE}=\text { Bias \% + CV }
$$

Absolute value of $\%$ average of Bland\&Altman plot differences were considered to be $\%$ bias and and total CVs of IgG, A and M as stated in Table 1.

Table 1. Total and within-run imprecision values of IgG, A and $M$

\begin{tabular}{clllll}
\hline & & $\begin{array}{l}\text { Mean } \\
(\mathrm{mg} / \mathrm{dL})\end{array}$ & $\begin{array}{l}\mathrm{SD} \\
(\mathrm{mg} / \mathrm{dL})\end{array}$ & $\begin{array}{l}\mathrm{CVw} \% \\
(\mathrm{ww}(\%)\end{array}$ & $\begin{array}{l}\mathrm{CVa} \\
\%\end{array}$ \\
\hline & Low QC level & 753.10 & 13.46 & 1.78 & \\
IgG & High QC level & 1148.05 & 33.78 & 2.94 & \\
& Human Serum & 1223.90 & 16.80 & & 1.37 \\
& Low QC level & 143.31 & 4.02 & 2.81 & \\
IgA & High QC level & 222.30 & 3.79 & 1.70 & \\
& Human Serum & 251.70 & 9.77 & & 3.88 \\
& Low QC level & 75.47 & 4.46 & 5.91 & \\
IgM & High QC level & 100.47 & 3.33 & 3.23 & \\
& Human Serum & 113.8 & 6.07 & & 5.34 \\
\hline
\end{tabular}

Low QC: low concentration quality control material, High QC: high concentration quality control material, SD: standart deviation, CVw: within-run precision, CVa: total precision

\section{Statistical Analysis}

Method comparison results were assessed using Bland\&Altman difference plots analysis to calculate the bias and limits of agreement. Data normality was assessed using Kolmogorov - Smirnov test. A Paired $t$ - test or Wilcoxon test was used to compare the mean values of methods. Values of $p<0.05$ were accepted as statistically significant. The nonparametric test of Spearman's rank and Pearson correlation tests were used to evaluate correlation between the results. MedCalc statistical software (ver.12.3.0.0.; Belgium) and SPSS 13.0 for Windows software (Chicago, IL) were used to perform calculations.

\section{RESULTS}

\section{Precision of Roche immunoturbidimetric Ig assays}

Calculation of within-run percentage coefficient variations $(\mathrm{CVw} \%)$ were based on 20 replicate measurements of selected samples per analytical run and total CVa \% (between-run) values obtained 
measuring human serum aliquotes in an internal protocol as 1 run per day and 10 days. The total results of precision studies are represented in Table 1.

\section{Limit of Detections (LoD) of Assays for Roche immunoturbidimetric Ig assays}

LoD values observed for immunoturbidimetric lgG, $\mathrm{A}$ and $\mathrm{M}$ on Roche Hitachi Modular $\mathrm{P}$ analyzer were $30.5 \mathrm{mg} / \mathrm{dL}, 4.63 \mathrm{mg} / \mathrm{dL}$ and $3.38 \mathrm{mg} / \mathrm{dL}$, respectively.

\section{Linearity for Roche immunoturbidimetric Ig assays}

\section{Across the reference range values}

Six dilutions of low and high level commercial quality control materials with the concentrations of related analytes which were close to the stated lower and upper limits (723-1110 mg/dL for IgG, 141-218 $\mathrm{mg} / \mathrm{dL}$ and $67.7-94.1 \mathrm{mg} / \mathrm{dL}$ for $\mathrm{lgM})$. Contrast to the presence of excess antigen, correlation between measured and calculated IgG $(R 2=0.989), \lg A(R 2$ $=0.987)$ and $\operatorname{lgM}(\mathrm{R} 2=0.970)$ was high.

\section{Presence of excess antigen}

Six dilutions derived from high and low concentration patient samples for each IgG $(8935 \mathrm{mg} / \mathrm{dL}$ - $961.4 \mathrm{mg} / \mathrm{dL}), \operatorname{lgA}(7470 \mathrm{mg} / \mathrm{dL}$ - $72 \mathrm{mg} / \mathrm{dL})$ and IgM (9184 mg/dL - $63.7 \mathrm{mg} / \mathrm{dL})$ were used to assess linearity in the presence of excess antigen. The observed results were compared to the theoretical (calculated) results for each dilutions of $\lg G, \lg A$ and IgM. Correlations between the calculated and measured values of $\lg G\left(R^{2}=0.662\right), A\left(R^{2}=0.707\right)$ and $M\left(R^{2}=0.685\right)$ were all low. Upper linearity limits for IgG, IgA and IgM were determined as $3500 \mathrm{mg} /$ $\mathrm{dL}, 775 \mathrm{mg} / \mathrm{dL}$ and $1800 \mathrm{mg} / \mathrm{dL}$, respectively.

\section{Sample carry-over on Roche immunoturbidimetric Ig assays}

The mean results of 3 replicate measurements of $\lg \mathrm{G}, \mathrm{A}$ and $\mathrm{M}$ assays performed using saline were $1.6 \mathrm{mg} / \mathrm{dL}, 0 \mathrm{mg} / \mathrm{dL}$ and $7.1 \mathrm{mg} / \mathrm{dL}$, respectively.

\section{Accuracy of Roche immunoturbidimetric Ig assays}

The results of our laboratory in RIQAS external quality assessments for cycle 47 for previous nine months were in acceptable limits for standard deviation index $(\mathrm{SDI}<2)$, total score $(\mathrm{TS}>50)$ and $\%$ deviation (DEV \% < defined acceptable limits) for our peer group of Roche Hitachi analyzer.

\section{Method comparison study}

IgG, $A$ and $M$ were measured in 451 serum samples by Roche Hitachi Modular $P$ and Dade Behring BNII nephelometer. The mean \pm SD value of IgG and mean and (min-max) values for IgA and IgM are summarized in Table 2. The obtained Spearman's rank correlation coefficients were 0.967, 0.979 and 0.939 for $\lg G$, IgA and $\lg M$, respectively.

Table 2. Comparison of results between two methods Roche Hitachi Modular P and Dade Behring BNII

\begin{tabular}{lllll}
\hline & $\mathrm{n} \quad \begin{array}{l}\text { Roche Hitachi } \\
\text { (Turbidimetric) }\end{array}$ & $\begin{array}{l}\text { Dade Behring BNII } \\
\text { (Nephelometric) }\end{array}$ & $\mathrm{R}^{2}$ \\
\hline $\lg \mathrm{(mg/dL})$ & 451 & $1351.86 \pm 803.56$ & $1375.95 \pm 861.53$ & 0.967 \\
$\operatorname{lgA}(\mathrm{mg} / \mathrm{dL})$ & $451261(166-367)$ & $232(148.5-335)$ & 0.979 \\
$\operatorname{lgM}(\mathrm{mg} / \mathrm{dL})$ & $451100(61.5-139.5)$ & $79(48.0-112.5)$ & 0.939 \\
\hline
\end{tabular}

$\mathrm{R}^{2}$ : indicates the correlation coefficients between the methods. Data represents median mean \pm SD for lgG assays and median (min. - max.) values for $\lg A$ and $M$ with $95 \%$ confidence interval.

Agreement between results obtained by immunoturbidimetric and nephelometric methods are demonstrated in different plots using Bland\&Altman. There was no evidence of systematic bias (found as $0.7 \%$ ) (limits of agreement, -26.0 to 27.4 ) for $\operatorname{lgG}$ (Figure 1). However the absolute values for systematic bias was $12.2 \%$ (limits of agreement, -46.0 to 21.7 ) for $\lg \mathrm{A}$ (Figure 2 ) and $22.2 \%$ (limits of agreement, -72.6 to 28.3 ) for IgM (Figure 3 ).

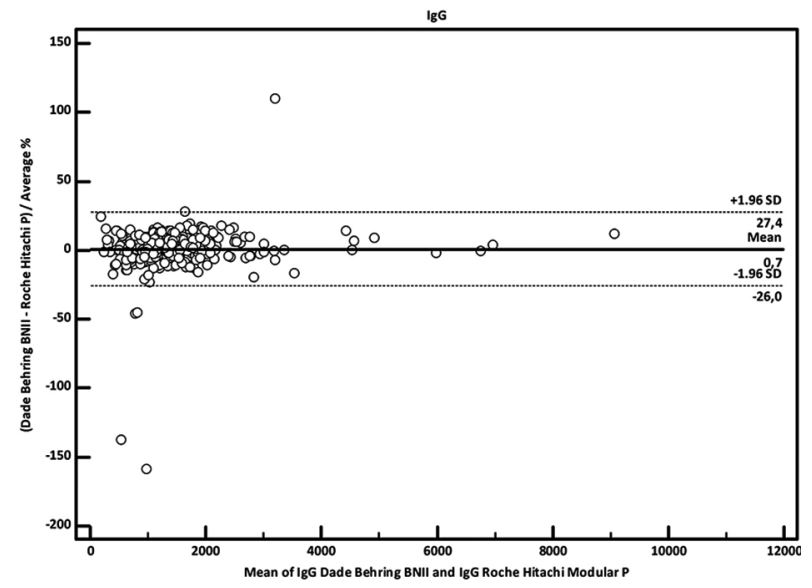

Figure 1. Bland\&Altman plots of the difference between Ig $G$ assays performed on Roche Hitachi Modular $P$ and Dade Behring BNII nephelometer against the mean Ig G values of 451 patients. 
IgA

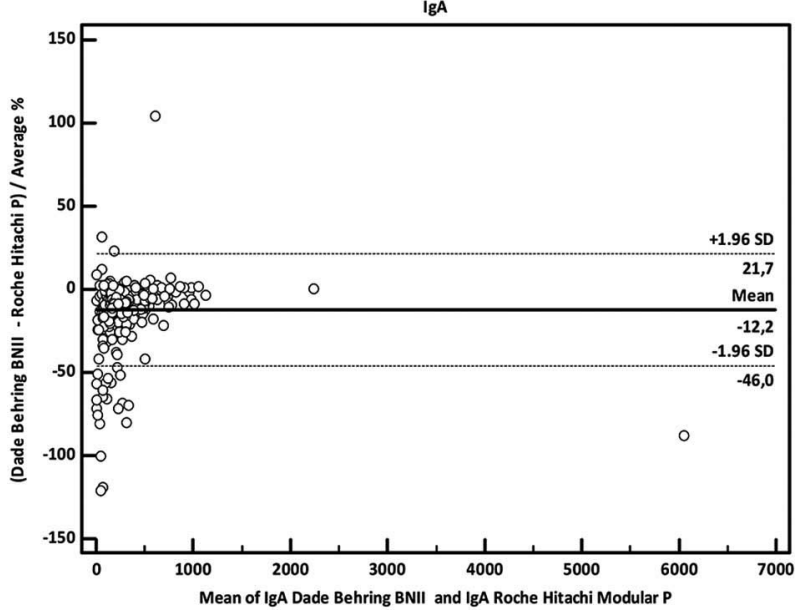

Figure 2. Bland\&Altman plots of the difference between $\lg A$ assays performed on Roche Hitachi Modular $P$ and Dade Behring BNII nephelometer against the mean $\lg \mathrm{A}$ values of 451 patients.

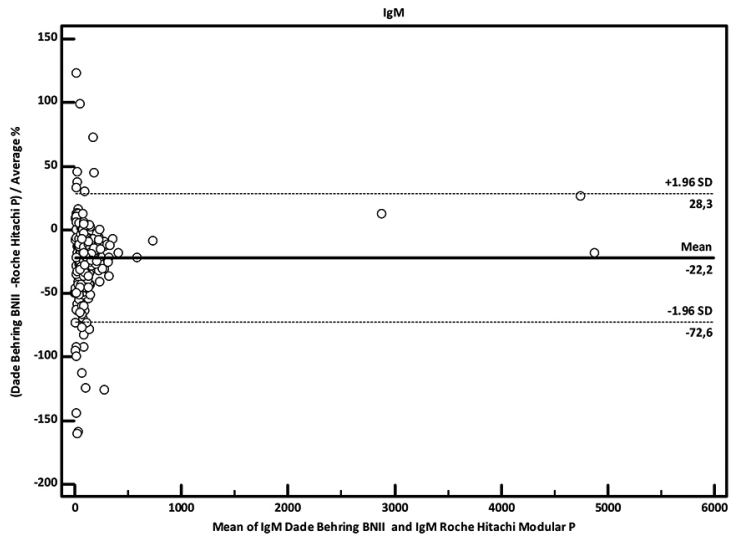

Figure 3. Bland\&Altman plots of the difference between $\lg \mathrm{M}$ assays performed on Roche Hitachi Modular $\mathrm{P}$ and Dade Behring BNII nephelometer against the mean Ig M values of 451 patients.

\section{Total error of Roche immunoturbidimetric Ig assays}

As calculated using the TE formula, TEs of Roche Hitachi Modular P for IgG, A and M turbidimetric assays were $2.07 \%, 16.08 \%$ and $27.5 \%$, respectively.

\section{DISCUSSION}

According to the literature we reviewed, there are no published articles for evaluation of the analytical performance of immunoglobulin assays on Roche Hitachi Modular P immunoturbidimetric method.
Desirable specifications for imprecision were obtained by using half of the with-in biological variation values of $\operatorname{lgG}, A$ and $M$ as given in http://www. westgard.com/database1.htm. In precision study we found total precision of $\lg G$ acceptable for the desirable quality specifications of total precision that is equal to $2.3 \%$ for $\lg$. However, both $\lg A$ and IgM had higher imprecisions than the desirable total precision which is $2.5 \%$ for $\operatorname{lgA}$ and $3.0 \%$ for lgM.

The judgment of acceptability depends on what amount of analytical error is allowable without affecting or limiting the use and interpretation of individual test results [10]. Total error concept composed of random error and systematic error was also evaluated for our study group data. Allowable total error limits were obtained from the charts summarized in http://www.westgard.com/database1.htm. We calculated TE for IgG as $2.07 \%$ where the allowable total error for this analyte was $8.0 \%$. TE for Roche Hitachi Modular $\mathrm{P}$ was also in acceptable limits for IgG as total precision was. However, Ig A with 16.08 $\%$ and IgM with $27.54 \%$ total error percentages both exceeded the allowable total error limits which are defined as $13.4 \%$ for $\lg A$ and $16.8 \%$ for $\lg \mathrm{M}$.

LoD values determined for IgG, $A$ and $M$ were $30.46 \mathrm{mg} / \mathrm{dL}, 4.63 \mathrm{mg} / \mathrm{dL}$ and $3.38 \mathrm{mg} / \mathrm{dL}$ verifying the data stated in manufacturer's kit inserts as $30 \mathrm{mg} / \mathrm{dL}, 4 \mathrm{mg} / \mathrm{dL}$ and $5 \mathrm{mg} / \mathrm{dL}$, respectively.

The equation in materials and methods section of this paper used for determining carry over assumes that any differences between each of three low concentration samples should contribute to only to with-in run precision if there is no carry over. Sample carry over coefficients (k) for IgG, IgA and IgM were all far below the CVs of the triple measurements indicating the absence of sample carry over.

Our results in Randox International Quality Assessment Scheme (RIQAS) external quality assessments for immunoturbidimetric immunoglobulin analysis were in acceptable limits for our peer group of Roche Hitachi analyzer, however it must be considered that the consensus mean values of $\lg G, A$ and $\mathrm{M}$ were all in the reference ranges and comparable to the results of immunonephelometry as the reference method. In order to avoid unreliable results in concentrations of immunoglobulins exceeding the linearity limits, further studies are thought to be needed to determine the linear limits for each immunoglobulin method before adapting immunoturbidimetric analysis in a clinical laboratory. 
There are different studies in the literature comparing immunoturbidimetric immunoglobulin assays against Dade Behring BN II immunonephelometer. Other analyzers such as Abbott Architect ci8200 had been compared to Beckman Immage for specific protein measurements by Denham et al [1]. In another study, immunoturbidimetric methods on Abbott Architect ci8200 were compared to Dade Behring BNII nephelometer for specific protein assays [11]. But as we reviewed there are no any reports comparing the results between immunoturbidimetric Roche Hitachi Modular P immunoglobulin analyses and Dade Behring BN II immunonephelometer Correlation coefficients between Roche immunoturbidimetric analysis and Dade Behring BN II immunonephelometer were $0.967,0.979$ and 0.939 for $\lg$, IgA and IgM respectively for $95 \%$ confidence interval (Table 2). It was suggested that the high correlation coefficients were associated with the mean values of $\lg G, A$ and $M$ all within reference intervals. A few data points represented as outliers were excluded which will lead marked discordance between the methods. Thus, correlation coefficients (R2) might be affected due to these excluded data.

In conclusion, Roche immunoturbidimetric lg analysis were found linear in the reference values but unreliable results were observed in the presence of excess antigen, because of impaired linearity. We found upper limits of linearity for IgG (3500 $\mathrm{mg} / \mathrm{dL})$ and $\mathrm{lgA}(775 \mathrm{mg} / \mathrm{dL})$ comparable to data presented in Roche $\lg$ ( $(3500 \mathrm{mg} / \mathrm{dL})$ and $\lg A(800$ $\mathrm{mg} / \mathrm{dL}$ ) manufacturer's kit inserts. For lgM, upper limit of linearity was approximately $1800 \mathrm{mg} / \mathrm{dL}$ was higher than the upper limit of linearity data given in Roche IgM (650 mg/dL) kit insert. In our study, patient samples including excess antigen performed on Dade Behring BN II nephelometer could be measured without dilution. The same samples performed on Roche Hitachi analyzers needed to be diluted suggesting BN II nephelometer had wider linearity range than Roche Hitachi immunoturbidimetric analyzer in the presence of excess antigen. We worked out the problem of linearity, diluting the samples serially which were including excess amounts of immunoglobulins till the values decreased to the midpoint of the reference values and following the \pm
$10 \%$ linearity recovery specifications between the equal concentration ranges of serial dilutions.

Declaration of interest: The authors report no declarations of interest. The authors alone are responsible for the content and writing of the paper.

\section{REFERENCES}

1. Morais IPA, Tóth IV, Rangel AOSS. Turbidimetric and nephelometric flow analysis: Concepts and Applications. Spectroscopy Letters. 2006;39:547-579.

2. Denham E, Mohn B, Tucker L, et al. Evaluation of immunoturbidimetric specific protein methods using the Architect ci8200: comparison with immunonephelometry.Clin Biochem. 2007;44:529-536.

3. Blirup-Jensen S. Protein standardization III: Method optimization basic principles for quantitative determination of human serum proteins on automated instruments based on turbidimetry or nephelometry. Clin Chem Lab Med 2001;39:1098-1109.

4. NCCLS EP5-A2. Evaluation of precision performance of quantitave measurement methods; approved guideline. NCCLS 2004; Villanova, Pennsylvania.

5. NCCLS EP17-A. Protocols for determination of limits of detection and limits of quantitation; approved guideline. NCCLS 2004; Villanova, Pennsylvania.

6. NCCLS EP6-A. Evaluation of the linearity of quantitaive measurement procedures: A statistical approach; approved guideline. NCCLS 2003; Villanova, Pennsylvania.

7. Chen Y, Yazdanpanah M, Hoffman BR, et al. Rapid determination of serum testosterone by liquid chromatography-isotope dilution tandem mass spectrometry and a split sample comparison with three automated immunoassays. Clin Biochem 2009;42:484-490.

8. Chen Y, Yazdanpanah M, Wang XY, et al. Direct measurement of serum free testosterone by ultrafiltration followed by liquid chromatography tandem mass spectrometry. Clin Biochem. 2010;43:490-496.

9. Fraser $C$, editor. Biological Variation:From Principles to Practice. Washington,DC: AACC Press 2001;29-67.

10. Ricos C, Alvarez V, Cava F, et al. Current databases on biological variation: pros, cons and progress. Scand J Clin Lab Invest 1999;59:491-500.

11. Mali B, Armbruster D, Serediak E, Ottenbreit T. Comparison of immunoturbidimetric and immunonephelometric assays for specific proteins. Clin Biochem 2009;42:1568-1571. 